\title{
KAJIAN DAN ADVIS PENYERTAAN MODAL DAERAH PADA PT. LEMBAGA KEUANGAN MIKRO (LKM) GARUT
}

\author{
Budiman $^{1}$, Lilis Sulastri ${ }^{2}$, Agus Joharudin ${ }^{3}$ \\ ${ }^{1,2,3}$ UIN Sunan Gunung Djati Bandung \\ Email: budiman@uinsgd.ac.id
}

\begin{abstract}
Abstrak
Studi ini bertujuan untuk mengkaji, serta memberikan advis tentang jumlah penyertaan modal ideal per tahun anggaran, yang selayaknya direalisasikan oleh Pemkab Garut pada PT LKM, serta proyeksi perolehan bagian laba (deviden) bagi pihak owner sebagai dampak penyertaan tersebut. Penelitian ini menggunakan metode deskriptif verifikatif dengan pendekatan kuantitatif, berbasiskan data laporan keuangan PT LKM tahun 2014-2018. Berdasarkan hasil evaluasi, secara umum kinerja keuangan PT LKM Garut tahun 2014-2018, menunjukkan perkembangan yang positif. Hal itu diindikasikan dengan pertumbuhan Asset dari Rp. 16,40 milyar menjadi Rp. 38,37 milyar; penyaluran Kredit dari Rp. 12,16 milyar menjadi Rp. 32,60 milyar; Tabungan dari Rp. 8,53 milyar (2016) menjadi Rp. 11,28 milyar (2018) dan Deposito dari Rp. 11,86 milyar menjadi Rp. 17,60 milyar (2018). Dari aspek kesehatan, sepanjang periode tersebut PT LKM Garut pun, berkategori Sehat sebagaimana yang ditunjukkan dengan capaian: Capital Adequacy Ratio (CAR), Kualitas Aktiva Produktif (KAP), Non Perfoming Loan (NPL), Cash Ratio, perbandingan Biaya Operasional dengan Pendapatan Operasional (BOPO), Return on Asset (RoA) dan Loan to Deposit Ratio (LDR). Perkembangan tersebut membawa konsekuensi pada meningkatnya kebutuhan realisasi penyertaan modal dari pihak owner. Guna meningkatkan kinerja dan perolehan Laba PT LKM, Pemkab disarankan untuk melakukan penyetoran modal minimal Rp. 1 milyar.
\end{abstract}

Kata Kunci: Advis, Penyertaan Modal Daerah, Kinerja PT LKM Garut.

\begin{abstract}
This study was aimed to examine and advise PT. Lembaga Keuangan Mikro (LKM) on capital inclusion adequacy. This study used a quantitative approach by using parametric statistics, and financial report analysis from 2014 to 2018. In this period, the performance of LKM was great. Its asset increased from Rp. 16.40 billion to Rp. 38.37 billion; its credit increased from $R p .12 .16$ billion to Rp. 32.60 billion; its savings increased from $R p .8 .53$ billion to Rp. 11.28 billion; and its deposits increased from Rp. 11.86 billion to Rp. 17.60 billion. Furthermore, LKM also has good key performing indices. The Capital Adequacy Ratio (CAR), Productive Asset Quality (PAQ), Non-Performing Loan, Cash Ratio, Operating Expense Ratio, (OER), Return on Asset, and Loan to Deposit Ratio (LDR) are all within healthy limits. This brings a good consequence in improving realization need in capital injection from the owner. As to increase PT. LKM performance, the government is suggested to give a capital at least 1 billion Rupiah.
\end{abstract}

Keywords: Advice, Municipal Capital Injection, Non-Bank Financial Institution Performance. 


\section{A. PENDAHULUAN}

Peran pemerintah dalam perekonomian, termasuk di dalamnya pemerintah daerah sangatlah strategis, baik dalam kapasitasnya sebagai fasilitator, regulator atau stimulator, bahkan sebagai pelaku ekonomi sekalipun. Peran tersebut tidak lagi diperdebatkan, baik dalam teori-teori maupun khasanah pemikiran ekonomi. Melalui berbagai kebijakan pada sektor publik, pemerintah mengambil peran dalam mendorong pertumbuhan ekonomi. Hal itu dapat dilakukan dalam bentuk penanaman modal (government investment), berupaya menarik investor, mendorong perkembangan teknologi, atau menghasilkan tenaga kerja yang dibutuhkan oleh bursa tenaga kerja (Hamid \& Anto, 1997).

Di beberapa negara, baik di negara sosialis maupun kapitalis, peran pemerintah dalam bidang investasi dan pembentukan modal (capital) cukup menonjol. Bahkan di Jepang dan Taiwan, lebih dari separuh pembentukan Gross Domestic Capital-nya dilakukan oleh pemerintah. Yang menarik, bahwa salah satu bentuk pengejawantahan peran pemerintah di negara-negara tersebut "dipercayakan" pada Badan Usaha Milik Negara (BUMN) yang diperankan sebagai salah satu mesin penggerak ekonomi, seperti halnya di Singapura dan Malaysia (Akadun, 2007). Dalam menjalankan peran tersebut, tentunya setiap negara memiliki strategi yang berbeda-beda. Di Indonesia, strategi menggerakkan roda perekonomian melalui Badan Usaha Milik Negara (BUMN) dan Badan Usaha Milik Daerah (BUMD), secara konstitusional dituangkan dalam Undang-undang Dasar Negara Republik Indonesia, pasal 33. Untuk BUMD, lebih lanjut diatur dalam Peraturan Pemerintah RI Nomor 57 Tahun 2017, tentang Badan Usaha Milik Daerah.

PT. Lembaga Keuangan Mikro (LKM) Garut merupakan BUMD relatif muda, berstatus sebagai Lembaga Keuangan Non Bank hasil merger dari 3 (tiga) lembaga keuangan sejenis pada tahun 2014 yang dibentuk dengan Peraturan Daerah Provinsi Jawa Barat Nomor 7 tahun 2015 sebagai BUMD milik bersama, antara Pemerintah Provinsi Jawa Barat dengan Pemerintah Kabupaten Garut, dengan komposisi kepemilikan saham: 91\% Pemkab Garut, dan 9\% Pemerintah Provinsi Jawa Barat. Sebagai BUMD yang masih berada dalam tahap introduksi, sekalipun dalam 4 (empat) tahun masa awal perjalanannya, menunjukkan trend kinerja yang terus membaik dan berkategori sehat, namun tingkat efisiensinya belum maksimal, karena sejauh ini pemenuhan kebutuhan modalnya masih menggunakan dana pinjaman, dengan bunga yang relatif tinggi. Hal itu dikarenakan belum terpenuhinya kewajiban setoran modal dari pihak owner sesuai dengan jumlah modal dasar yang ditentukan. Apabila kondisi ini terus berlangsung, sangat mungkin perkembangan PT LKM Garut ke depan akan terkendala. Untuk itu, diperlukan kajian dan advis guna mendorong konsistensi pihak owner dalam memenuhi kewajiban setoran modal dimaksud, sesuai dengan skema yang ditentukan dalam Perda Penyertaan Modal. Selain dari itu, seluruh costumers PT LKM, diharapkan dapat menjadikan kajian ini, sebagai pegangan dalam upaya meningkatkan kinerja BUMD tersebut, sehingga misi utamanya sebagai kontributor PAD, dan penopang pengembangan sektor UKM, dapat tercapai.

Kajian ini bertujuan untuk memberikan gambaran, sekaligus masukan kepada pihak owner PT. LKM Garut berkenaan dengan rencana penyertaan modal Pemkab Garut khususnya, dan perkiraan return dan benefit yang akan didapat oleh owner serta stake holders lainnya, apabila direalisasikan secara tepat waktu dan tepat jumlah. Penelitian ini juga bertujuan untuk memberikan investment advise atau rekomendasi kepada pihak owner dan 
manajemen PT LKM terkait dengan pengalokasian dana penyertaan modal secara efektif dan produktif.

\section{B. TINJAUAN PUSTAKA}

\section{Investasi}

Menurut Sukirno (2001) kegiatan investasi yang dilakukan oleh masyarakat secara terus menerus akan meningkatkan kegiatan ekonomi dan kesempatan kerja, meningkatkan pendapatan nasional dan taraf kemakmuran masyarakat. Pandangan ini bertolak dari tiga fungsi penting kegiatan investasi, yakni:

a. Investasi merupakan salah satu komponen dari pengeluaran agregat, sehingga kenaikan investasi akan meningkatkan permintaan agregat, pendapatan nasional serta kesempatan kerja;

b. Pertambahan barang modal sebagai akibat investasi akan menambah kapasitas produksi;

c. Investasi umumnya diikuti pula dengan perkembangan teknologi untuk pembangunan ekonomi yang bersumber dari luar negeri.

\section{Pendapatan Asli Daerah}

Pendapatan Asli Daerah (PAD) adalah penerimaan yang diperoleh daerah dari sumber-sumber dalam wilayahnya sendiri, yang dipungut berdasarkan Peraturan Daerah sesuai dengan peraturan perundang-undangan yang berlaku (Pasal 1 Undang-Undang RI Nomor 33 Tahun 2004). Dengan kata lain, Pendapatan Asli Daerah merupakan sumber pendapatan asli dan berasal dari potensi daerah yang bersangkutan. Pemerintah daerah dapat mengoptimalkan sumber PAD tersebut melalui berbagai kebijakan, baik secara ekstensif maupun intensif. Sumber-sumber PAD secara umum berasal dari: 
a. Hasil Pajak Daerah

Pajak Daerah adalah kontribusi wajib kepada daerah yang terutang oleh orang pribadi atau badan, yang bersifat memaksa berdasarkan undang-undang, dengan tidak mendapatkan imbalan secara langsung dan digunakan untuk keperluan daerah bagi sebesar-besarnya kemakmuran rakyat (Pasal 1 Undang-Undang RI Nomor 28 Tahun 2009).

b. Hasil Retribusi Daerah

Retribusi Daerah, adalah pungutan daerah sebagai pembayaran atas jasa atau pemberian izin tertentu yang khusus disediakan dan/atau diberikan oleh pemerintah daerah untuk kepentingan orang pribadi atau badan (Pasal 1 Undang-Undang Nomor 28 Tahun 2009).

c. Hasil Pengelolaan Kekayaan Daerah Yang Dipisahkan

Bagi daerah yang memiliki BUMD seperti: Perusahan Daerah Air Minum, Bank Pembangunan Daerah Badan Kredit Kecamatan, PD Pasar, atau tempat hiburan/rekreasi dan sejenisnya, maka sebagian laba yang didapatkan oleh badan usaha atau atas hasil kekayaan daerah yang dipisahkan tersebut, merupakan sumber penghasilan bagi daerah yang bersangkutan (Nurcholish, 2005). Menurut Ahmad Yani (2002) hasil pengelolaan kekayaan daerah yang dipisahkan, antara lain berupa bagian laba, deviden, dan penjualan saham milik daerah.

d. Lain-lain PAD yang Sah

Menurut Pasal 6 Undang-undang RI Nomor 33 Tahun 2004 tentang Perimbangan Keuangan antara Pemerintah Pusat dan Daerah, yang dimaksudkan dengan Lainlain PAD yang Sah meliputi: Hasil penjualan kekayaan daerah yang tidak dipisahkan, jasa giro, pendapatan bunga, keuntungan selisih nilai tukar rupiah terhadap mata uang asing dan komisi, potongan, ataupun bentuk lain sebagai akibat dari penjualan dan/atau pengadaan barang dan/atau jasa oleh pemerintah daerah.

\section{Penyertaan Modal Daerah}

Modal (capital) merupakan sumber daya utama penggerak aktivitas perusahaan. Keberadaan modal dalam sebuah perusahaan, berkaitan dengan keseluruhan harta perusahaan yang diputarkan atau digunakan dalam menjalankan kegiatan usaha. Ketidakmemadaian modal usaha akan berimplikasi pada keterbatasan perusahaan dalam mengelola aktivitasnya, dan akan bermuara pada kemampuan mendapatkan laba. Menurut Riyanto (2001) yang dikutip dari pendapat Meij, modal diartikan sebagai kolektivitas dari barang-barang modal yang terdapat dalam neraca sebelah debet, sedangkan yang dimaksudkan dengan barangbarang modal adalah semua barang yang ada dalam rumah tangga perusahaan dalam fungsi produktifnya untuk membentuk pendapatan. Dengan demikian, modal adalah keseluruhan harta perusahaan yang terdapat pada sisi pasiva neraca, baik yang termasuk ke dalam golongan hutang lancar, maupun harta tetap. Riyanto (2001) dengan mengutip pendapat Polak, mengartikan modal sebagai kekuasaan untuk menggunakan barang-barang modal. Dengan kata lain, modal adalah barang-barang modal yang terdapat pada neraca sebelah kredit. Yang dimaksud dengan barang-barang modal adalah barang-barang yang terdapat dalam perusahaan yang belum digunakan, yang terdapat dalam neraca sebelah debet. Dari beberapa pengertian di atas dapat disimpulkan, bahwa modal adalah keseluruhan harta 
perusahaan yang ditanam (invested) dalam kegiatan usaha, baik berupa harta tetap, harta lancar maupun harta tak terwujud, yang dicatat dalam neraca.

Perda Provinsi Jawa Barat Nomor 13 Tahun 2016 tentang Penyertaan Modal Daerah, mengartikan Penyertaan Modal Daerah sebagai setiap usaha dalam menyertakan modal daerah pada suatu usaha bersama antar daerah, dan/atau dengan badan usaha swasta/badan lain dan/atau pemanfaatan modal daerah oleh badan usaha/badan lain dengan suatu maksud, tujuan dan imbalan tertentu. Penyertaan Modal Pemerintah Daerah dimaksudkan sebagai upaya meningkatkan produktivitas pemanfaatan tanah dan/atau bangunan serta kekayaan lainnya milik Pemerintah Daerah dengan membentuk usaha bersama dan saling menguntungkan. Tujuan Penyertaan Modal Pemerintah Daerah adalah untuk meningkatkan:

a. Sumber Pendapatan Asli Daerah;

b. Pertumbuhan ekonomi;

c. Pendapatan masyarakat; dan

d. Penyerapan tenaga kerja.

Untuk mencapai tujuan tersebut, Penyertaan Modal Pemerintah Daerah seyogianya berpegang pada prinsip-prinsip tata kelola usaha yang baik (good corporate governance). Perencanaan penyertaan modal pemerintah daerah diatur dalam Peraturan Daerah, dan dalam pelaksanaannya dikoordinasikan oleh Dinas Pengelolaan Keuangan dan Aset Daerah dan Tim Penasihat Investasi Pemkab berdasarkan prinsip kehati-hatian (prudent) agar penyertaan modal tersebut berjalan efektif, efisien dan produktif..

\section{METODE}

Penelitian ini menggunakan metode deskriptif verifikatif yang didukung dengan pendekatan kuantitatif. Metode kuantitatif digunakan dalam menghitung nominal rencana penyertaan modal dan proyeksi laba yang akan didapat (regresi linier sederhana dan Analisis Rasio Keuangan). Pendekatan deskriptif dimaksudkan sebagai metode deskriptif analisis, guna menggambarkan suatu keadaan secara utuh dalam bentuk tulisan dan dianalisis secara sistematis. Data dari Laporan Keuangan PT. Lembaga Keuangan Mikro Garut tahun 2014 sampai dengan 2018 dan Laporan Keuangan Pemkab Garut tahun 2012-2018. Data kemudian dihimpun dan dianalisis guna memperoleh penjelasan mengenai korelasi antar variabel penelitian. Studi bertujuan menganalisis kontribusi penyertaan modal daerah terhadap kinerja PT LKM.

Untuk menghitung besaran penyertaan modal, digunakan dua analisis. Pertama, analisis perkembangan usaha PT. LKM tahun 2014-2018 dilihat dari nilai aset, pendapatan, likuiditas dan volume kredit. Kedua, analisis kinerja keuangan PT LKM yang meliputi : Capital Adequacy Ratio (CAR), Return on Asset (ROA), Loan to Deposits Ratio (LDR), Operating Expense Ratio (OER), Cash Ratio, Non Performing Loan (NPL), dan rasio Aktiva Produktif (Mulyawan, 2015; Setia Mulyawan, 2015).

\section{HASIL DAN PEMBAHASAN}

\section{Analisis Perkembangan Usaha PT. LKM Garut}

Perkembangan usaha PT LKM Garut sepanjang tahun 2014-2018 trend-nya terus meningkat. Hal ini diindikasikan dengan bertambahnya nilai aset, likuiditas, volume kredit dan pendapatan bunga. Pada tahun 2014 (awal merger) nilai aset berjumlah Rp. 16,40 miliar, 
dan akhir tahun 2018 meningkat menjadi Rp 38,37 milyar. Kas dan setara kas (likuiditas) mencapai Rp. 2,6 milyar, sehingga mampu meningkatkan volume Kredit menjadi Rp 32,60 milyar atau naik sebesar $133,96 \%$ dan menghasilkan pendapatan yang berasal dari jasa (bunga) sebesar Rp.0,456 milyar. Dengan demikian, sepanjang tahun 2014-2018 perkembangan usaha PT LKM Garut terus meningkat sebagaimana tampak pada Gambar 1 dan Gambar 2 di bawah ini:

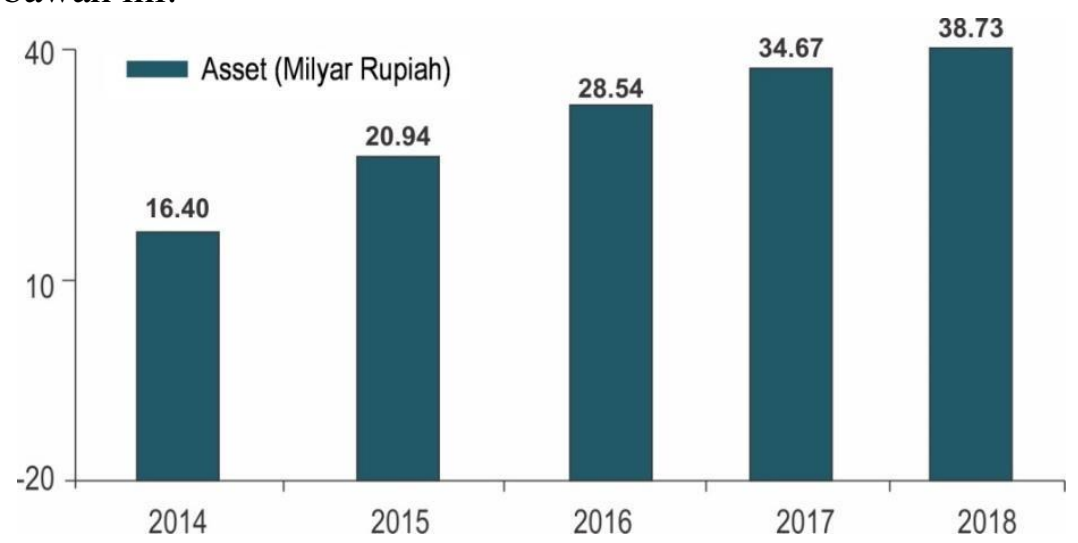

Gambar 1. Perkembangan Nilai Aset PT LKM Garut Tahun 2014-2018

Gambar di atas, memperlihatkan nilai aset PT LKM yang terus meningkat sepanjang 4 (empat) tahun terakhir. Dari Rp. 16,40 milyar pada tahun 2014, menjadi Rp. 20,94 milyar pada tahun 2015 atau naik 27,68\%; tahun 2016 bertambah menjadi Rp. 28,54 milyar, atau naik 40,66 persen. Tahun 2017 menjadi Rp. 34,67 milyar, atau meningkat sebesar 21,48 persen, dan pada tahun 2018 berjumlah Rp. 38,37 milyar, atau naik 10,76\%. Dengan demikian, nilai aset rata-rata perusahaan per tahun, mencapai Rp. 5,65 milyar, atau 25,75\%. Peningkatan aset tersebut meningkatkan kapasitas PT LKM Garut dalam menyalurkan kreditnya, baik kredit produktif, kredit konsumtif, sehingga memperbesar peluang perolehan Laba secara kumulatif.

Perkembangan Tabungan, Deposito dan Volume Kredit sepanjang tahun 2014-2018 dapat dilihat pada Gambar 2 di bawah ini:

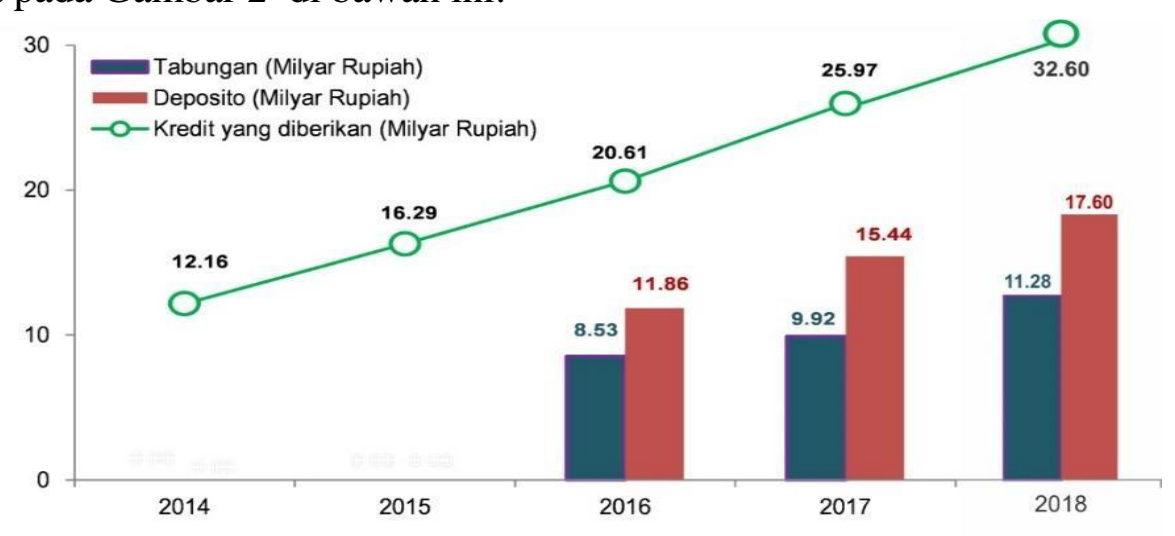

Gambar 2. Perkembangan Kredit, Tabungan dan Deposito PT LKM Garut Thn. 20142018

Jumlah Tabungan PT LKM sepanjang tahun 2016 sampai tahun 2018 terus meningkat. Dari Rp. 8,53 miliar (2016), menjadi Rp. 9,92 miliar (tahun 2017) dan naik menjadi Rp. 11,28 miliar pada tahun 2018. Deposito pada kurun waktu yang sama meningkat cukup pesat, yaitu sebesar 30\% (dari Rp 11,86 menjadi Rp 15.440 milyar). Pesatnya pertumbuhan dana deposito tersebut mendorong PT LKM untuk menaikkan suku bunga 
deposito menjadi sebesar 8,25\%. Kondisi ini memungkinkan PT LKM mampu meningkatkan volume kreditnya dari tahun ke tahun, yaitu: dari Rp. 12,16 milyar (tahun 2014) naik menjadi Rp. 16.29 milyar (tahun 2015), artinya meningkat Rp.4,13 milyar (33,96\%) dan pada tahun 2016 meningkat kembali menjadi Rp. 20,61 milyar atau naik Rp.4,32 milyar (26,52\%). Pada tahun 2017, bertambah menjadi sebesar Rp. 25,97 milyar, atau naik menjadi 5,36 milyar rupiah (26\%), sehingga per tahun `rata-rata naik sebesar Rp. 4.6 milyar (28,82 persen).

Perolehan dan pertumbuhan Laba bersih PT LKM Garut tahun 2014-2018, tampak pada Gambar 3 di bawah ini:

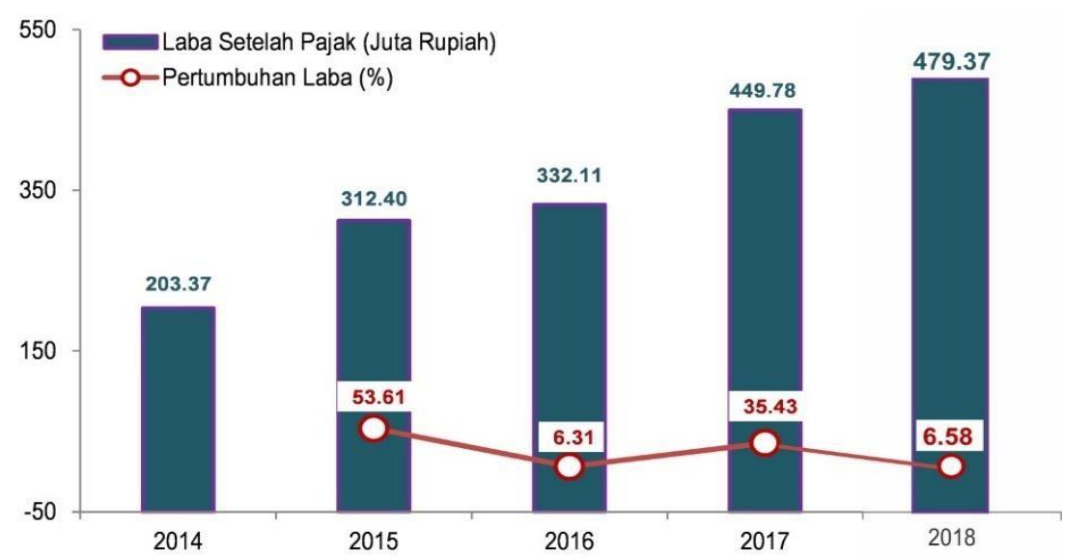

Gambar 3. Perkembangan Laba Setelah Pajak PT. LKM Garut Tahun 20142018

Jumlah Laba Setelah Pajak PT LKM, selama 4 tahun berturut turut, meningkat dari Rp. 203,37 juta (tahun 2014) menjadi Rp. 312,40 juta pada tahun 2015, kemudian naik menjadi Rp. 332,11 juta (tahun 2016), meningkat kembali menjadi Rp. 449,78 juta pada tahun 2017, dan tahun 2018 mencapai Rp. 479,37 juta. Hal ini mengandung arti kenaikan Laba PT LKM Garut rata-rata per tahun, mencapai sebesar Rp. 55,2 juta atau sebesar $25,48 \%$.

\section{Kinerja Keuangan PT. LKM Garut}

Secara umum kinerja keuangan PT LKM Garut berkategori sehat, hal ini tampak dari sejumlah indikator kinerja keuangannya yang meliputi: CAR, KAP, NPL, ROA, BOPO, CASH RATIO dan LDR. Capaian indikator kinerja PT LKM tahun 2016 -2018, secara rinci dapat dilihat pada tabel berikut:

Tabel 1. Tingkat Kesehatan PT. LKM Garut Tahun 2016-2018 (\%)

\begin{tabular}{|c|c|c|c|c|c|c|c|}
\hline Indikator & $\begin{array}{l}\text { Kriteria } \\
\text { Sehat }\end{array}$ & $\begin{array}{l}\text { Rasio } \\
\text { Tahun } 2016\end{array}$ & Keterangan & $\begin{array}{l}\text { Proyeksi } \\
2017\end{array}$ & Ktgn & $\begin{array}{l}\text { Proyeksi } \\
2018\end{array}$ & Ktgn \\
\hline CAR & $>=8$ & 29,16 & Sehat & 19,4 & Sehat & 23.58 & Sehat \\
\hline KAP & $<=10,35$ & 2,11 & Sehat & 2,65 & Sehat & 1.60 & Sehat \\
\hline $\begin{array}{l}\text { NPL } \\
\text { GROS }\end{array}$ & $<=10$ & 3,03 & Sehat & 2,60 & Sehat & 1.74 & Sehat \\
\hline $\begin{array}{l}\text { NPL } \\
\text { NET }\end{array}$ & $<=10$ & 0,64 & Sehat & 2,60 & Sehat & & \\
\hline ROA & $>=1,215$ & 1,20 & Sehat & 1,46 & Sehat & 1.55 & Sehat \\
\hline
\end{tabular}


ARTIKEL

\begin{tabular}{llllllll}
\hline BOPO & $<=93,52$ & 94,42 & Kurangsehat & 93,42 & Sehat & 91.76 & Sehat \\
\hline $\boldsymbol{C A S H}$ & $>=4,05$ & 24,37 & Sehat & 8,00 & Sehat & 10.40 & Sehat \\
$\boldsymbol{R A T I O}$ & & & & & & & \\
LDR & $<=94,75$ & 72,94 & Sehat & 84,66 & Sehat & 85.63 & Sehat
\end{tabular}

Sumber: Laporan Tahunan PT LKM Garut Tahun 2018.

Capital Adequacy Ratio (CAR) PT LKM Garut tahun 2017 sebesar 19,4\%, atau menurun sebesar 9,76\% dibandingkan dengan tahun 2016 yang mencapai 29,16\%, dan tahun 2018 meningkat menjadi 23,58\%. Walaupun CAR tahun 2016-2018 masih berada pada batas aman yaitu $>=8$, namun bagi pihak manajemen, penurunan tersebut patut menjadi catatan, mengingat semakin rendah $C A R$ akan berdampak pada turunnya kemampuan lembaga dalam menanggung risiko kredit/aktiva produktif. CAR yang semakin menurun, mengandung arti pula, bahwa kemampuan perusahaan dalam membiayai kegiatan operasional dan probabilitas capaian laba akan menurun. Secara normatif, rasio kecukupan moda/CAR PT LKM Garut, masih tergolong baik.

Kualitas Aktiva Produktif (KAP), pada tahun 2016 tercatat sebesar 2,11\% atau berpredikat Sehat, karena batas maksimal dinyatakan sehat sebesar 10,35\%. Periode 2017 sebesar 2,65\% atau mengalami kenaikan sebesar 0,54\%, dan tahun 2018 sebesar 1,60\%. Hal ini terjadi akibat menurunnya jumlah Aktiva Produktif yang disalurkan, dan kenaikan jumlah Aktiva Produktif yang berisiko. Walaupun masih berada dalam batas normal, sesungguhnya mengindikasikan kondisi yang kurang baik,

Rasio Non Performing Loan (NPL) tahun 2017 sebesar 2,60, artinya mengalami kenaikan sebesar 0,43\% dibandingkan dengan tahun 2016, dan tahun 2018 mencapai angka 1,74\%. Apabila dilihat perkembangannya sepanjang tahun 2016-2018, secara normatif rasio tersebut masih termasuk dalam kategori sehat, karena di bawah 5\%.

Dari data diketahui, nilai ROA periode 2017 adalah 1,46\% yang diperoleh dari laba sebelum pajak. Nilai ROA periode 2017 mengalami kenaikan sebesar 0,26\% dan tahun 2018 mencapai angka $1,55 \%$, hal ini dimungkinkan karena terdapat kenaikan total aktiva yang diikuti dengan kenaikan laba. Jadi, ROA periode 2016-2018 berpredikat sehat/baik, karena naik di atas $1,22 \%$.

Rasio BOPO tahun 2016 sebesar 94,42\%. Artinya berpredikat kurang sehat karena nilainya lebih dari 93,52\%. Rasio BOPO tahun 2017 sebesar 93,42\% atau turun sebesar $1 \%$. Tahun 2018 turun kembali menjadi 91,76\%. Hal ini menunjukkan adanya penurunan beban operasional dibanding periode sebelumnya, akan tetapi diimbangi dengan adanya kenaikan pada sisi pendapatan operasional. Jadi, BOPO periode 2016-2018 berpredikat sehat karena di bawah angka maksimal (93,52\%).

Dari tabel di atas diketahui nilai CR periode 2016 sebesar 24,37\%. Standar CR berpredikat sehat adalah minimal 4,05\%. Jadi, CR periode 2016 berpredikat sehat karena nilainya lebih dari 4,05\%. Nilai CR periode 2017 diketahui sebesar $8 \%$. Atau mengalami penurunan sebesar 16,37\%. Tahun 2018 naik menjadi 10,40\%, dimungkinkan karena jumlah utang lancar bertambah dan ketersediaan dana likuid bertambah. Secara umum, LDR PT LKM tahun 2016-2018 termasuk sehat karena kurang dari 93,75\%. 


\section{Pembagian Laba PT LKM Garut}

Besarnya bagian laba tahunan bagi pemilik (deviden), dihitung dari jumlah perolehan laba tahun berkenaan, berdasarkan besaran pemilikan saham dan realisasi setoran modal dari masing-masing owner, sebagaimana tergambar pada tabel berikut:

Tabel 2. Komposisi Saham Pemkab Garut dan Pemprov Jabar pada PT LKM Garut

\begin{tabular}{|c|c|c|c|c|}
\hline No & Pemegan Saham & Besarnya (Rp) & \% & Modal Disetor (Rp) \\
\hline 1 & Pemprov. Jabar & $1,350,000,000$ & 9 & $1,350,000,000$ \\
\hline 2 & Pemkab. Garut & $13,650,000,000$ & 91 & $9,500,000,000$ \\
\hline & Jumlah & $\mathbf{1 5 , 0 0 0 , 0 0 0 , 0 0 0}$ & $\mathbf{1 0 0}$ & $\mathbf{1 0 , 8 5 0 , 0 0 0 , 0 0 0}$ \\
\hline
\end{tabular}

Bagian saham PT LKM Garut yang dimiliki Pemerintah Provinsi Jawa Barat sebesar 9\%, dengan Realisasi Modal Disetor sejumlah Rp.1.350.000.000, sedangkan Pemerintah Kabupaten Garut menguasai saham sebesar 91\% dengan jumlah realisasi Modal Disetor sebesar Rp.9.500.000.000. Jumlah Laba PT LKM Garut tahun 2018 sebesar Rp.479.367.731,00 atau naik sebesar Rp.29.589.295,00 (6,58 persen) jika dibandingkan dengan Laba Tahun 2017 yang mencapai Rp. 449.775.436. Dengan komposisi kepemilikan saham tersebut, pembagian laba masing-masing share holder sebagai berikut :

Tabel 3. Pembagian Laba PT LKM Tahun 2018

\begin{tabular}{|c|l|c|r|r|}
\hline No & \multicolumn{1}{|c|}{$\begin{array}{c}\text { Pemegang } \\
\text { Saham }\end{array}$} & \% & Laba 2018 & \\
\hline 1 & Pemprov. Jabar & 9 & $479,367,731$ & $43,143,096$ \\
\hline 2 & Pemkab. Garut & 91 & 479.367 .731 & 436.224 .635 \\
\hline & Jumlah & $\mathbf{1 0 0}$ & & \\
\hline
\end{tabular}

Tahun 2018 Pemrov Jabar mendapatkan deviden sebesar Rp.43.143.096, sedangkan Pemkab Garut dengan kepemilikan saham 91\%, mendapatkan bagian Laba (deviden) sebesar Rp. 436.224.635.

\section{Kontribusi Penyertaan Modal Daerah Terhadap Laba PT. LKM Garut}

Analisis keterkaitan Penyertaan Modal Daerah, Nilai Aset dan volume Kredit PT LKM Garut selama 4 tahun (tahun 2014-2018), memperlihatkan kaitan yang positif. Artinya, bahwa meningkatnya jumlah penyertaan modal berdampak positif terhadap peningkatan asset PT LKM. Demikian pula terhadap volume kredit yang diberikan, dan pendapatan perusahaan. Peningkatan ini menghasilkan kenaikan kontribusi PT LKM dalam bentuk bagian Laba (deviden) bagi para owner, sekalipun bila dibandingkan dengan pertumbuhan aset-nya, pertumbuhan laba tersebut sesungguhnya masih tergolong rendah.

Grafik berikut menggambarkan Perkembangan Asset, Laba Setelah Pajak, dan Kontribusi Laba PT LKM Garut terhadap Pendapatan Asli Daerah Kabupaten Garut, dari tahun 2014 sd tahun 2018: 


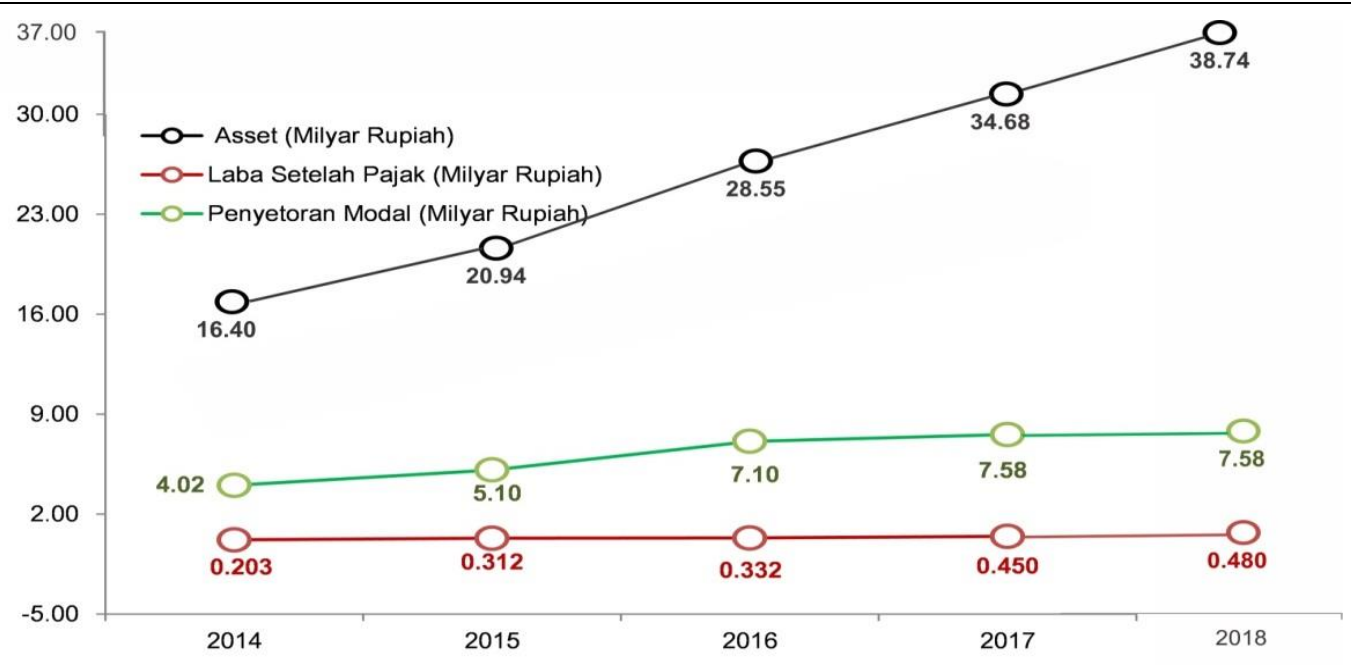

Untuk memprediksi perolehan Laba PT LKM dan jumlah deviden atau bagian Laba pihak pemilik, dihitung dengan cara memproyeksikan Penyertaan Modal Daerah terhadap Laba Setelah Pajak, melalui model regresi linier sederhana. Dalam hal ini, Laba setelah Pajak ditempatkan sebagai variabel dependen dan Penyertaan Modal Daerah sebagai variabel independen, dengan formulasi sebagai berikut:

\section{LABA BUMD = 49,298,133+ 0.065 PMD}

Keterangan: PMD : Penyertaan Modal Daerah (dalam Ribuan Rupiah)

Hipotesis dari perhitungan tersebut adalah: Jika Pemkab Garut tidak melakukan penyertaan modal, maka PT LKM akan mendapatkan Laba sebesar Rp. 49.289.133, dan bilamana dilakukan Penyertaan Modal sebesar Rp. 1 milyar, maka Laba BUMD akan naik sebesar 0.065 kali jumlah nominal penyertaan modal, ditambah dengan Rp. 49.289.133. Jumlah tersebut bersifat prediktif, yang dihitung melalui model regresi linear sederhana dengan taraf signifikansi sebesar 5\% (F hitung $=0,028$ ), dan untuk variabel dependen dengan nilai konstanta sebesar 0,065. Meskipun nilai konstanta tidak signifikan, model ini, lazim digunakan untuk memprediksi jumlah Laba PT LKM untuk satu tahun ke depan/mendatang. Proyeksi perolehan laba PT LKM per tahun atas setiap realisasi penyertaan modal Pemkab Garut, selengkapnya dapat dilihat pada tabel berikut:

Tabel 4. Proyeksi Laba PT. LKM Garut pada Berbagai Jumlah Penyertaan Modal

Tahun 2014-2019

\begin{tabular}{|c|c|c|c|}
\hline Tahun & $\begin{array}{c}\text { Penyertaan Modal } \\
\text { Pemkab Garut (Rp) }\end{array}$ & $\begin{array}{c}\text { Proyeksi Laba BUMD (Rp) } \\
\text { Y = 49,298,133+ 0.065 (X) }\end{array}$ & $\begin{array}{c}\text { Laba BUMD } \\
\text { Riil (Rp) }\end{array}$ \\
\hline s.d 2014 & $4,020,325,209$ & $310,619,271.6$ & $203,371,604$ \\
\hline 2015 & $6,520,325,209$ & $473,119,271.6$ & $312,399,306$ \\
\hline 2016 & 8.520 .325 .209 & $603,119,271.6$ & $332,106,128$ \\
\hline 2017 & 9.000 .000 .000 & $634,298,133$ & $447,777,000$ \\
\hline 2018 & 9.500 .000 .000 & $666,798,133$ & 479.367 .731 \\
\hline $\mathbf{2 0 1 9}$ & $\mathbf{1 0 . 0 0 0 . 0 0 0 . 0 0 0}$ & $699,298,133$ & \\
\hline
\end{tabular}

Sumber: Laporan Keuangan PT. LKM Garut, 2014-2018, Diolah Kembali. 
Jumlah penyertaan modal pada tabel di atas merupakan akumulasi selama 6 tahun anggaran. Untuk mendapatkan gambaran perolehan bagian laba (deviden), dapat dihitung dengan cara mengurangkan jumlah Penyertaan Modal tahun yang diproyeksikan, dengan jumlah penyertaan modal pada tahun sebelumnya. Misalnya untuk mendapatkan Laba setelah Pajak sebesar Rp. 699.298.133,- Pemkab Garut pada tahun 2019 perlu melakukan penambahan Penyertaan modal, minimal sebesar Rp. 500.000.000,-. Angka tersebut, dihitung dari asumsi jumlah akumulasi Penyertaan Modal Pemkab Garut sampai dengan tahun 2019, yaitu Rp. 10.000.000.000 dikurangi dengan Rp. 9.500.000.000,-

\section{E. KESIMPULAN}

Kinerja keuangan PT LKM Garut sepanjang Tahun Anggaran 2016 sampai dengan Tahun Anggaran 2018, tergolong Sehat sebagaimana tercermin dari sejumlah indikator utama kinerja keuangan lembaga tersebut, yang meliputi: Capital Adequacy Ratio (CAR), Kualitas Aktiva Produktif (KAP), Non Perfoming Loan (NPL), Cash Ratio, perbandingan Biaya Operasional dengan Pendapatan Operasional (BOPO), Return on Asset (RoA) dan Loan to Deposit Ratio (LDR).

Penambahan Penyertaan Modal Daerah/Pemkab pada PT LKM Garut, berdampak positif terhadap kenaikan nilai aset, volume kredit dan Laba setelah Pajak (Earning after Tax) Setiap penambahan penyertaan modal sebesar Rp. 1 milyar, diprediksi mendapatkan Laba sebesar 0,065 kali jumlah nominal realisasi penyertaan modal plus Rp. 49.289.133, dan jika tidak dilakukan penyertaan modal, PT LKM akan mendapatkan laba sebesar Rp. 49.289.133,00.

Dalam upaya meningkatkan kinerja PT LKM Garut, sekaligus mendorong peningkatan deviden, pada setiap tahun anggaran Pemkab Garut disarankan dapat menambah Penyertaan modal kepada, minimal Rp. 1 milyar. Pihak manajemen PT LKM Garut, diharapkan dapat meningkatkan sejumlah indikator kinerja keuangan yang masih tergolong rendah atau bahkan mengalami penurunan.

\section{DAFTAR PUSTAKA}

Akadun. (2007). Administrasi Perusahaan Negara. Bandung: Alfabeta.

Hamid, E. S. \& Anto, M. B. H. (1997. Telaah Pembangunan Ekonomi Indonesia. Economic Journal of Emerging Markets, 2(1), 16-28.

Mulyawan, S. (2015). Manajemen Keuangan. Bandung: Pustaka Setia.

Mulyawan, S. (2015). The Benefits of Financial Ratios as the Indicators of Future Bankruptcy on the Economic Crisis. International Journal of Nusantara Islam, 3(1), 21-30.

Nurcholish, H. (2005) Teori dan Praktik Pemerintahan dan Otonomi Daerah. Jakarta: Gramedia Widiasarana Indonesia.

Peraturan Daerah Provinsi Jawa Barat Nomor 13 Tahun 2006 tentang Penyertaan Modal Daerah.

Peraturan Pemerintah Republik Indonesia Nomor 1 Tahun 2008 tentang Investasi Pemerintah. 
Peraturan Pemerintah Republik Indonesia Nomor 54 Tahun 2017 tentang Badan Usaha Milik Daerah.

Riyanto, B. (2001). Dasar-Dasar Pembelanjaan Perusahaan. Yogyakarta: BPFE.

Sukirno, S. (2001). Pengantar Teori Makro. Jakarta: RajaGrafindo Persada.

Yani, A. (2002). Hubungan Keuangan antara Pemerintah Pusat dan Daerah di Indonesia. Jakarta: RajaGrafindo Persada. 